\title{
POZYCJA USTROJOWA WŁADZY WYKONAWCZEJ W POLSCE W ASPEKCIE WYKONYWANIA WYROKÓW EUROPEJSKIEGO TRYBUNAŁU PRAW CZŁOWIEKA - WYBRANE ZAGADNIENIA
}

Przestrzeganie przez państwa zobowiązań prawno-międzynarodowych z Europejskiej Konwencji o Ochronie Praw Człowieka i Podstawowych Wolności dnia z 4 listopada 1950 r. (dalej jako: Konwencja, EKPC) jest dwojakie: po pierwsze jest to wprowadzanie $\mathrm{w}$ systemie prawa wewnętrznego odpowiednich standardów poszanowania praw i wolności jednostki zapisanych w tym traktacie; po drugie jest to obowiązek wykonywania orzeczeń Europejskiego Trybunału Praw Człowieka (dalej jako: Trybunał, ETPCz) w sytuacji stwierdzenia naruszania Konwencji.

Zainteresowanie orzeczeniem ETPCz ustaje najczęściej w dniu jego wydania, kiedy to spór pomiędzy skarżącym a państwem zostaje zakończony. Jednak wydanie orzeczenia przez ETPCz, które stwierdza naruszenie Konwencji jest tylko zakończeniem sądowego etapu postępowania, otwierającym jednocześnie kolejny, nie mniej ważny dla obu stron sporu (państwa i jednostki) - etap wykonania wyroku Trybunału, czyli jego implementacji przez władze krajowe. Przedmiotem niniejszego opracowania jest prezentacja kompetencji i zakresu umocowania ustrojowego władzy wykonawczej w Polsce w przedmiocie wykonywania wyroków ETPCz.

\section{Wprowadzenie}

Zgodnie z art. 46 ust. 1 Konwencji „Wysokie Układające się Strony zobowiązują się do przestrzegania ostatecznego wyroku Trybunału we wszystkich sprawach, w których są stronami”. Postanowienia EKPC nie określają ani rodzajów organów krajowych, które powinny podejmować działania mające na celu wykonanie wyroku Trybunału, ani też rodzaju podejmowanych przez nie działań ${ }^{1}$. Jest to kompetencja wewnętrzna państwa, oparta o podstawy prawno-ustrojowe prawa wewnętrznego. Zakorzenienie ETPCz w systemie Rady Europy predysponuje system kontroli wyHuman Rights, (w:) T.A. Christou, J.P. Raymond (ed.), European Court of Human Rights, remedies and execution of judgments, „British Institute of International and Comparative Law” 2005, s. 3. 
konywania wyroków przez państwa - strony EKPC, gdzie kompetencje te wykonuje Komitet Ministrów Rady Europy (dalej jako: KM). Ciężar odpowiedzialności za wykonanie wyroku Trybunału spoczywa na państwie, a KM sprawuje jedynie nadzór nad prawidłowością przebiegu procesu wykonania wyroku Trybunału (art. 39 EKPC). Państwu pozostawiona jest swoboda co do wyboru środków, które mają zostać przedsięwzięte $\mathrm{w}$ procesie implementacji. To państwo proponuje konkretne rozwiązania, a KM ocenia stopień ich kompletności i adekwatności - w zależności od tego, co stanowiło źródło naruszenia Konwencji stwierdzonego przez Trybunał. Nie zmienia to jednak faktu, że podejmowane działania w przedmiocie wykonania wyroku ETPCz muszą dawać gwarancje skutecznego wykonania orzeczenia Trybunału².

W 1958 r. KM po raz pierwszy zajmował się sprawą wynikłą ze skargi wniesionej na podstawie EKPC, stąd też praktyka jego działania ma już rozbudowaną formułę. Według art. 6 ust. 2 Regulaminu Komitetu Ministrów ws. nadzoru nad wykonaniem wyroków i warunków ugód z dnia 10 maja 2006 r. KM bada, czy słuszne zadośćuczynienie przyznane przez Trybunał zostało zapłacone, w tym również, w zależności od sytuacji - odsetki oraz czy zostały podjęte przez państwo tzw. środki indywidualne lub środki generalne ${ }^{3}$. Środki indywidualne ${ }^{4}$ są podejmowane w celu zapewnienia, by naruszenie ustało, a także by pokrzywdzona strona została postawiona, na ile to możliwe, w tej samej sytuacji, z której korzystała przed naruszeniem Konwencji - tzw. restitutio in integrum. W katalogu środków indywidualnych można wyróżnić m.in.: wznowienie zaskarżonych postępowań krajowych, skreślenie nieuzasadnionego skazania karnego z rejestru karnego czy przyznanie pozwolenia na pobyt ${ }^{5}$. Drugi typ środków tzw. środki generalne ${ }^{6}$ są ukierunkowane

2 Zob. szerzej: Execution of judgments of the European Court of Human Rights - introduction, Department for the Execution of Judgments of the European Court of Human Rights, Council of Europe, Strasbourg, H/Exec(2004)2. Rozstrzygając aspekt, które wyroki ETPCz podlegają reżimowi traktatowemu w zakresie ich wykonania należy stwierdzić, iż na równi należy traktować w tym przedmiocie zarówno wyroki niekorzystne dla państwa-strony, jak również zatwierdzone przez ETPCz porozumienia polubowne między państwem-stroną a skarżącym. Wykonaniu podlegają wyłącznie ostateczne wyroki co oznacza, iż z procedury wykonywania orzeczenia ETPCz wyłączeniu podlegają: opinie doradcze, rozstrzygnięcia proceduralne, wyroki dotyczące jurysdykcji Trybunału oraz wyroki interpretacyjne.

3 Rules of the Committee of Ministers for the supervision of the execution of judgments and of the terms of friendly settlements (Adopted by the Committee of Ministers on 10 May 2006 at the 964th meeting of the Ministers' Deputies) https://wcd.coe.int/ViewDoc.jsp?id=999329, (data dostępu: 25.9.2015 r.) oraz lit. b, Zalecenia CM/ Rec(2008)2 Komitetu Ministrów dla państw członkowskich dotyczące skutecznej zdolności krajowej do szybkiego wykonywania wyroków Europejskiego Trybunału Praw Człowieka (przyjęte przez Komitet Ministrów 6.2.2008 r., na 1017. posiedzeniu Komitetu Ministrów), (w:) Zalecenia Rady Europy dla państw członkowskich dotyczące wzmacniania mechanizmów wdrażania Konwencji o ochronie praw człowieka i podstawowych wolności na poziomie krajowym, Warszawa 2014, s. 26; D. Forst, The Execution of Judgments of the European Court of Human Rights - Limits and Ways Ahead, „Vienna Journal on International Constitutional Law“ 2013, no. 3, s. 1.

4 Council of Europe, Department of the Execution of Judgments, 'List of individual measures' H/Exec (2006)2 April 2006 available at $\mathrm{http} / / / \mathrm{www}$. coe.int/t/dghl/monitoring/execution/Documents/Mlindex_en.asp (last consultation on 3 July 2012) (data dostępu: 8.10 .2015 r.).

5 http://www.coe.int/t/dghl/monitoring/execution/Presentation/Pres_Exec_en.asp (data dostępu: 25.9.2015 r.).

6 Cuncil of Europe, Department of the Execution of Judgments, General measures adopted to prevent new violations of the European Convention on Human Rights, H/Exec(2006)1 May 2006 available at http://www.coe.int/t/ dghl/monitoring/execution/Documents/MGindex_en.asp (data dostępu: 8.10.2015 r.). 
na zapobieganie nowym naruszeniom podobnym do tych stwierdzonych orzeczeniem lub wyeliminowanie trwających naruszeń ${ }^{7}$. Wybór zastosowania odpowiednich środków generalnych jest uzależniony od okoliczności i może polegać na np.: przeglądzie ustawodawstwa i związanych z tym zmian legislacyjnych (w tym norm konstytucyjnych), zmianie praktyki organów krajowych czy publikacji orzeczeń ETPCz w języku danego państwa ${ }^{8}$.

W przypadku gdy dokonanie zmian w prawie czy praktyce krajowej, bądź podjęcie innych odpowiednich środków, które mają stanowić wykonanie wyroku ETPCz, wymaga dłuższego czasu, KM może żądać od państwa podjęcia tzw. środków tymczasowych, które mają na celu zapobieganie podobnym stwierdzonym naruszeniom, zanim zostaną podjęte szersze i ostateczne środki.

\section{Konstytucyjne kompetencje Rady Ministrów w zakresie wykonywania wyroków Europejskiego Trybunału Praw Człowieka}

Prowadzenie polityki zagranicznej polega na konstytucyjnie i ustawowo określonej działalności organów państwa, związanej z regulowaniem stosunków między Rzeczpospolitą Polską a podmiotami międzynarodowymi oraz innymi uczestnikami stosunków międzynarodowych ${ }^{9}$. Konstytucja RP z 2 kwietnia 1997 r. dzieli kompetencję do prowadzenia polityki zagranicznej między Radę Ministrów, Prezydenta oraz Sejm i Senat, przy czym tylko rządowi przypisana jest wprost kompetencja „prowadzenia polityki zagranicznej" ${ }^{10}$. Zgodnie z art. 146 ust. 1-2 i ust. 4 pkt 9 Konstytucji RP z 1997 r. ${ }^{11}$, organem odgrywającym w Polsce przewodnią rolę w wykonywaniu wyroków ETPCz jest Rada Ministrów ${ }^{12}$.

Regulacja art. 146 Konstytucji RP przyznaje rządowi kompetencje ogólnego kierownictwa w dziedzinie stosunków z innymi państwami i organizacjami międzynarodowymi, a co za tym idzie również Radą Europy, w systemie której działa ETPCz. Art. 146 ust. 4 pkt 9 Konstytucji wskazujący, iż rząd ,sprawuje ogólne kierownictwo w dziedzinie stosunków z innymi państwami i organizacjami międzyrządowymi”,

7 J. Granowska, Wykonywanie wyroków Europejskiego Trybunału Praw Człowieka przez Polskę - podstawowe informacje. Materiały na posiedzenie Komisji Praw Człowieka, Praworządności i Petycji w dniu 16 maja 2012 r., Warszawa 2012, s. 2-3.

$8 \quad$ Ibidem, s. 2.

9 L. Mażewski, Prowadzenie polityki zagranicznej w Rzeczypospolitej Polskiej, „Ruch Prawniczy, Ekonomiczny i Socjologiczny" 2009, nr 3, s. 9.

10 Ibidem, s. 9.

11 „Art. 146. 1. Rada Ministrów prowadzi politykę wewnętrzną i zagraniczną Rzeczypospolitej Polskiej. 2. Do Rady Ministrów należą sprawy polityki państwa nie zastrzeżone dla innych organów państwowych i samorządu terytorialnego. (...) 4. W zakresie i na zasadach określonych w Konstytucji i ustawach Rada Ministrów w szczególności: (...) 9) sprawuje ogólne kierownictwo w dziedzinie stosunków z innymi państwami i organizacjami międzynarodowymi,(...)". Konstytucja Rzeczypospolitej Polskiej z dnia 2 kwietnia1997 r. (Dz.U. z 1997 r. Nr 78, poz. 483 z póź. zm.).

12 M. Grzybowski, System rządów w Rzeczypospolitej Polskiej: charakterystyka i diagnoza wątpliwości. Uwagi wprowadzające, „Przegląd Prawa Konstytucyjnego” 2012, nr 1, s. 130 i n.; D. Górecki (red.), Polskie prawo konstytucyjne, Warszawa 2012, s. 202 i n. 
oznacza nie tylko posiadanie kompetencji do podejmowania decyzji o charakterze strategicznym, ale także istnienie odpowiedniej struktury organizacyjnej w państwie, poprzez którą powyższe decyzje byłyby konkretyzowane, a następnie realizowane ${ }^{13}$, jak jest w przypadku wypełniania zobowiązań prawno-międzynarodowych wynikających z członkostwa w Radzie Europy, w tym podleganie jurysdykcji ERPCz. Kompetencja Rady Ministrów w zakresie wykonywania wyroków Trybunału została resortowo umiejscowiona w kompetencjach Ministerstwa Spraw Zagranicznych (dalej jako: MSZ). W strukturze MSZ powołano specjalnego Pełnomocnika Ministra Spraw Zagranicznych do spraw postępowań przed ETPCz (dalej jako: Pełnomocnik) ${ }^{14}$. Podstawą prawną powołania Pełnomocnika było Zarządzenie $\mathrm{Nr} 7 \mathrm{Mi}$ nistra Spraw Zagranicznych z dnia 27 października 2003 r. w sprawie ustanowienia i zadań Pełnomocnika Ministra Spraw Zagranicznych do spraw postępowań przed Europejskim Trybunałem Praw Człowieka ${ }^{15}$. Zgodnie z $§ 1$ ust. 2 Zarządzenia, Pełnomocnika wyznacza i odwołuje Minister Spraw Zagranicznych w drodze decyzji. Do jego zadań należy przede wszystkim pełnienie w imieniu MSZ funkcji koordynacyjnej w zakresie współpracy między resortami rządowymi i innymi podmiotami zaangażowanymi w wykonywanie wyroków ETPCz. Inne funkcje Pełnomocnika to m.in.: ${ }^{16}$ reprezentowanie RP jako strony w postępowaniach skargowych prowadzonych przed ETPCz, koordynacja wykonywania orzeczeń Trybunału na szczeblu konstytucyjnych organów państwa, organów administracji rządowej i samorządowej ${ }^{17}$, przewodniczenie Zespołowi ds. ETPCz powołanemu w celu koordynacji wykonywania orzeczeń ETPCz, przygotowywanie planów działań i raportów z aktywności podjętych przez władze polskie w celu realizacji wyroków ETPCz, opracowywanie projektów rocznych informacji nt. wykonywania wyroków ETPCz dla Rady Ministrów, opiniowanie pod względem zgodności ze standardami EKPCz projektów aktów prawnych rozpatrywanych przez RM oraz koordynacja procesu thumaczenia wyroków ETPCz, jak też innych dokumentów Rady Europy i Trybunału dotyczących standardów praw człowieka.

Reasumując, w zakresie kompetencji organów krajowych w przedmiocie wykonywania wyroków ETPCz, za koordynację całego procesu wykonywania wyroków odpowiada MSZ (poprzez prace powołanego w 2007 r. międzyresortowego Zespołu ds. Europejskiego Trybunału Praw Człowieka, któremu przewodniczy Pełnomocnik). Natomiast za wykonywanie poszczególnych orzeczeń Trybunału - odpowiada MSZ i odpowiednie przedmiotowo resorty, które muszą ściśle współpracować, aby

.

Zarządzenie Nr 7 z dnia 27.10.2003 r. Ministra Spraw Zagranicznych w sprawie ustanowienia i zadań Pełnomocnika Ministra Spraw Zagranicznych do spraw postępowań przed Europejskim Trybunałem Praw Człowieka (Dz. Urz. MSZ z 2003 r. Nr 4, poz. 53 z późn. zm.).

Dz.Urz. MSZ z 2003 r. Nr 4, poz. 53 z późn. zm.

http://www.sejm.gov.pl/sejm7.nsf/InterpelacjaTresc.xsp?key=59EC45FA (data dostępu: 14.10 .2015 r.).

Ponadto powołany został - podległy Pełnomocnikowi - Zastępca ds. koordynacji wykonywania wyroków ETPCz, którego działalność obejmuje funkcje wspomagająco-koordynacyjne w przedmiocie wykonywania wyroków Trybunału. 
Pozycja ustrojowa władzy wykonawczej w Polsce w aspekcie wykonywania wyroków...

zapewnić efektywność realizacji orzeczenia ETPCz w polskim systemie prawa i w praktyce organów krajowych.

\section{Działania władzy wykonawczej w Polsce w zakresie wykonywania wyroków Europejskiego Trybunału Praw Człowieka}

Tematyka wykonywania wyroków ETPCz obecna jest w dyskursie naukowym w Polsce od co najmniej kilkunastu lat, kiedy to liczba orzeczeń wydawanych przez Trybunał przeciwko RP przestała mieć charakter incydentalny, a stała się utrwaloną praktyką. Ale nie sposób nie zauważyć, iż ożywiona dyskusja ma także swoje źródło w poszukiwaniu metod, a co za tym idzie, skuteczności wykonywania przez Polskę wyroków ETPCz. Dlatego też warto jest przyjrzeć się bliżej Programowi Działań Rządu w sprawie wykonywania wyroków Europejskiego Trybunału Praw Człowieka wobec Rzeczypospolitej oraz działalności międzyresortowego Zespołu do spraw Europejskiego Trybunału Praw Człowieka.

\subsection{Program Działań Rządu w sprawie wykonywania wyroków Euro-} pejskiego Trybunału Praw Człowieka wobec Rzeczypospolitej oraz kompetencje międzyresortowego Zespołu do spraw Europejskiego Trybunału Praw Człowieka

Program Działań Rządu w sprawie wykonywania wyroków Europejskiego Trybunału Praw Człowieka wobec Rzeczypospolitej (dalej jako: Program) został przyjęty przez Radę Ministrów w dniu 17 maja 2007 r. Propozycje działań zawarte w Programie wskazują, iż: „W celu zwiększenia skuteczności wykonywania wyroków Trybunału, a przede wszystkim zapobiegania stwierdzania naruszenia przez Polskę Konwencji, co pociąga za sobą znaczne skutki finansowe, należy podjąć systematyczne działania mające na celu poprawę ustawodawstwa i praktyki w dziedzinie praw człowieka w Polsce"18. Program Działań Rządu w sprawie wykonywania wyroków ETPCz, zgodnie z nazwą - ma charakter programowy, nie przesądza konkretnych kierunków przyszłych rozwiązań, zwłaszcza prawnych, które kształtują się pod wpływem bieżących orzeczeń Trybunału. Program składa się z sześciu części:

- Część I stanowi wprowadzenie prawne do specyfiki zobowiązań prawnomiędzynarodowych wynikających z EKPC, w tym obowiązku wykonywania orzeczeń ETPCz.

- Część II pt. „Polepszanie prawa i praktyki krajowej” wymienia szesnaście obszarów, w których uznano za konieczne wprowadzenie zmian zgodnie z orzecznictwem ETPCz. Są to m.in.: zasady stosowania tymczasowego aresztowania i pozbawienia wolności, przewlekłość postępowań sądowych 
i administracyjnych, rozszerzenie dostępu do sądu, cenzura korespondencji osób pozbawionych wolności z Trybunałem czy wzmocnienie skuteczności prawa rodziców do kontaktów z dzieckiem itd.

- Część III pt. „Upowszechnianie wiedzy na temat Konwencji o ochronie praw człowieka i podstawowych wolności oraz orzecznictwa Europejskiego Trybunału Praw Człowieka, to katalog działań edukacyjnych w społeczeństwie oraz omówienie sposobów upowszechniania standardów praw człowieka wśród organów, sądów i innych instytucji.

- Część IV pt. „Instrumenty międzynarodowe” charakteryzuje kierunki działań oraz uzasadnienie dla Polski do przystąpienia do Europejskiego porozumienia $\mathrm{w}$ sprawie osób uczestniczących w postępowaniu przed ETPCz. Rozważa też kwestie związane z podjęciem przez Polskę inicjatywy opracowania protokołu Dodatkowego do EKPC, dotyczącego gwarancji praw ofiar przestępstw w postępowaniach karnych.

- Część V pt. „Wspótpraca ministrów” jest szczególnie istotną częścią Programu, bowiem określa zasady współpracy między Ministrem Spraw Zagranicznych i pozostałymi ministrami $\mathrm{w}$ związku z problematyką skarg komunikowanych przez ETPCz i wykonywaniem wydawanych wyroków (bezpośrednim skutkiem było powołanie w późniejszym czasie stałego międzyresortowego Zespołu ds. ETPCz).

- Część VI pt. „Realizacja Programu Działań Rzadu” omawia zasady współpracy międzyresortowej w zakresie wykonywania wyroków ETPCz.

\subsection{Dzialalność międzyresortowego Zespołu do spraw Europejskiego Try- bunału Praw Czlowieka.}

Realizacja Programu Działań Rządu w sprawie wykonywania wyroków Europejskiego Trybunału Praw Człowieka została oparta o działalność stałej międzyresortowej struktury - Zespołu do spraw Europejskiego Trybunału Praw Człowieka (dalej jako: Zespół). Podstawą prawną utworzenia Zespołu było Zarządzenie Nr 73 Prezesa Rady Ministrów z dnia 19 lipca 2007 r. ${ }^{19}$ Zespół ma charakter organu opiniodawczo-doradczego Prezesa Rady Ministrów. Do jego najważniejszych funkcji należy wypracowywanie strategii Rady Ministrów w przedmiocie komunikowanych Polsce skarg, które wpływają do Trybunału, jak i wydawanych przez ETPCz wyroków, analizowanie zgodności z Konwencją projektów aktów prawnych, z którymi mogą się wiązać istotne skutki dla prawa lub praktyki w Polsce, a także przedstawianie stosownych propozycji w zakresie wykonania wyroków ETPCz.

Procedura pracy Zespołu przewiduje odbywanie obrad członków na posiedzeniach plenarnych, odbywających się co kwartał. Poza posiedzeniami plenarnymi, Zespół pracuje w grupach roboczych, składających się z przedstawicieli resortów 
odpowiedzialnych za wykonanie wyroku Trybunału (według właściwości przedmiotowej resortu adekwatnej do rodzaju sprawy), gdzie formułowane są propozycje podjęcia odpowiednich działań mających na celu wykonanie wyroku Trybunału ${ }^{20}$.

\subsection{Wykonywanie wyroków przez Radę Ministrów a współpraca z Parla- mentem RP}

W ostatnich latach ważnym obszarem $\mathrm{w}$ procesie wykonywania wyroków ETPCz w Polsce jest powstanie współpracy pomiędzy Radą Ministrów i Parlamentem. W kwietniu 2012 r. rozpoczęto praktykowanie wspólnych spotkań przedstawicieli MSZ - w tym Pełnomocnika MSZ ds. postępowań przed ETPCz - z Komisją Sprawiedliwości i Praw Człowieka Sejmu RP oraz z Komisją Praw Człowieka, Praworządności i Petycji Senatu RP, w sprawach dotyczących wykonywania orzeczeń ETPCz w Polsce ${ }^{21}$. Bezpośrednim rezultatem prowadzonych wspólnie konsultacji było ukonstytuowanie w dniu 05 lutego 2014 r. Podkomisji sejmowej ds. wykonywania wyroków ETPCz (dalej jako: Podkomisja) ${ }^{22}$, której członkowie zostali powołani podczas wspólnego posiedzenia sejmowych Komisji Sprawiedliwości i Praw Człowieka oraz Komisji Spraw Zagranicznych. Do zadań Podkomisji należy rozpatrywanie informacji Rady Ministrów na temat stanu wykonywania przez Polskę wyroków ETPCz, monitorowanie wyroków Trybunału, które zostały wydane w sprawach przeciwko Polsce i przygotowanie informacji nt. realizacji przez Radę Ministrów obowiązku wykonania przez Polskę wyroków Trybunału² ${ }^{23}$. Fakt powołania wyspecjalizowanej podkomisji sejmowej jest wyrazem coraz większego włączania parlamentu w proces wykonywania wyroków ETPCz. Jest to również kolejny etap działań na rzecz wzmocnienia współpracy pomiędzy rządem i parlamentem w kierunku skuteczniejszej implementacji orzecznictwa Trybunału w polskim systemie prawnym i praktyce organów krajowych - zostało to pozytywnie ocenione na gremium Zgromadzenia Parlamentarnego Rady Europy ${ }^{24}$.

20 Raport z wykonania wyroków Europejskiego Trybunału Praw Człowieka przez Polskę za 2012 r., Ministerstwo Spraw Zagranicznych - Pełnomocnik Ministra Spraw Zagranicznych do spraw postępowań przed Europejskim Trybunałem Praw Człowieka, Warszawa 26.3.2013 r., s. 1; http://www.msz.gov.pl/pl/polityka_zagraniczna/europejski_trybunal_praw_czlowieka/wykonywanie_orzeczen_europejskiego_trybunalu_praw_czlowieka/ (data dostępu: 23.9 .2015 r.).

21 Raport z wykonania wyroków ETPCz przez Polskę za 2012 r..., op. cit., s. 2.

22 Pełny zapis przebiegu posiedzenia Komisji Sprawiedliwości i Praw Człowieka (nr 156) Komisji Spraw Zagranicznych (nr 119) 5.2.2014 r., Kancelaria Sejmu Biuro Komisji Sejmowych, Warszawa 2014, s. 3-4.

23 Pełny zapis przebiegu posiedzenia Komisji Sprawiedliwości..., op. cit., s. 4; Informacja, Wydział VII Prawa Europejskiego w Biurze Orzecznictwa NSA, „Biuletyn Europejski” 2014, nr 3 (4), s. 2.

24 Parliamentary Assambly, The role of parliaments in implementing ECHR standards: overview of existing structures and mechanisms. Background memorandum prepared by the Secretariat, Strasbourg 2015, PPSD (2014) 22 rev. 8 September 2015, s. 5. 


\section{Polska przed Europejskim Trybunałem Praw Człowieka}

Nadzór sprawowany przez Komitet Ministrów nad wykonywaniem wyroków ETPCz nie zdoła oczywiście zapobiec wnoszeniu kolejnych skarg do ETPCz, dotyczących nowych, złożonych problemów z zakresu przestrzegania praw i wolności człowieka ${ }^{25}$. Jednakże KM odgrywa ważną rolę w kontroli, czy pozwane państwa nie podchodzą zbyt minimalistycznie do stwierdzonych naruszeń oraz czy podejmują niezwłocznie działania mające na celu przeciwdziałanie dalszym, podobnym naruszeniom EKPCz - tzw. „sprawy klonowe” (clone cases) lub sprawy powtarzające się co do stwierdzanych naruszeńn ${ }^{26}$.

Niezależnie od wszelkich starań podejmowanych w celu zapewnienia skutecznego wykonywania wyroków ETPCz, sytuacja w Polsce, jak i w innych państwach członkowskich Rady Europy w dalszym ciągu nie jest najlepsza, zarówno w zakresie liczby wnoszonych skarg do ETPCz, jak i liczby wydawanych corocznie orzeczeń przez Trybunał. Obrazują to poniżej przedstawione dane statystyczne z lat 2000 -2014 .

\section{Wykres 1.}

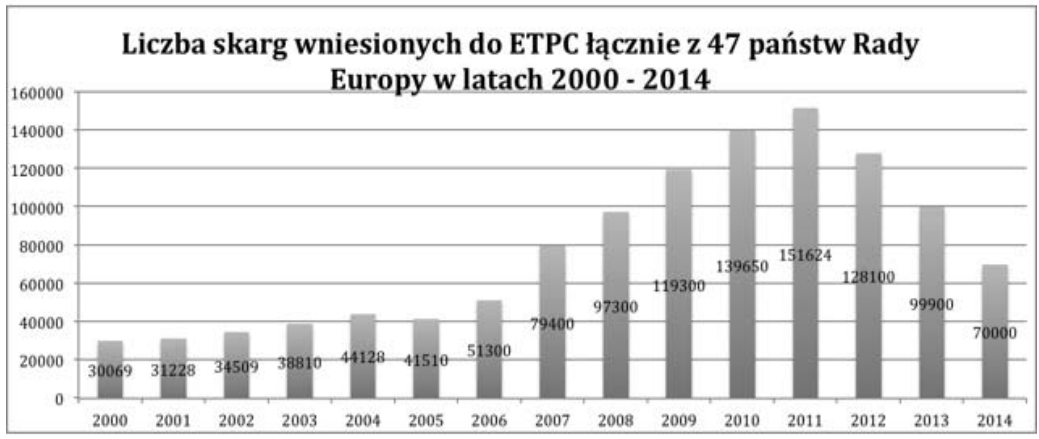

Źródto: opracowanie własne na podstawie European Court of Human Rights Annual Report ECHR z lat 2000-2014, www.echr.coe.int (data dostępu: 23.09.2015 r.). 
Pozycja ustrojowa władzy wykonawczej w Polsce w aspekcie wykonywania wyroków...

Wykres 2.

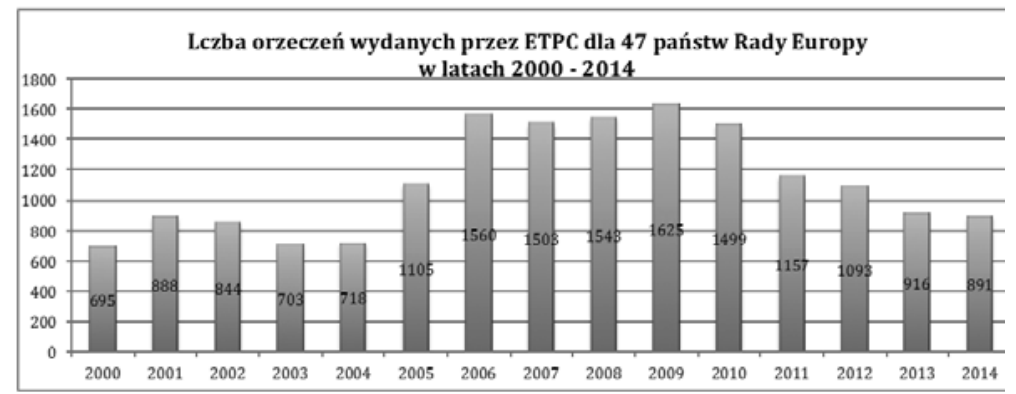

Źródto: opracowanie wtasne na podstawie European Court of Human Rights Annual Report ECHR z lat 2000-2014, www.echr.coe.int (data dostęu: 23.09.2015 r.).

\section{Wykres 3.}

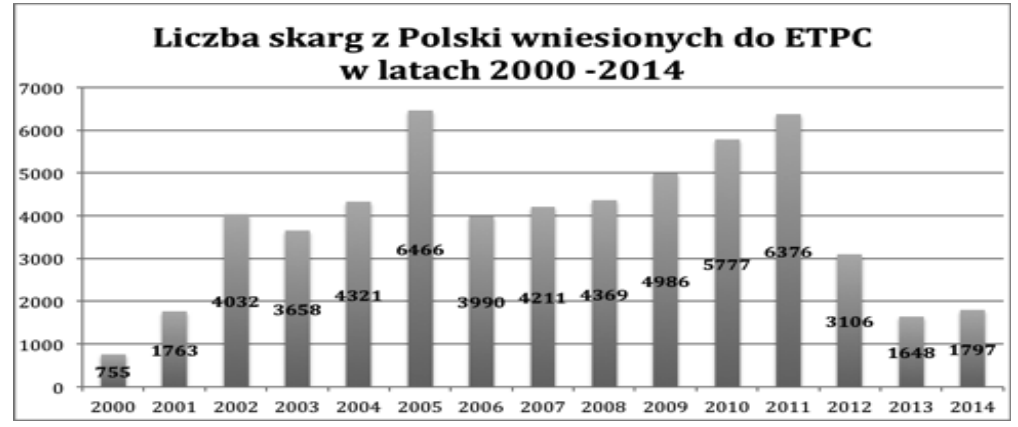

Źródło: opracowanie wlasne na podstawie European Court of Human Rights Annual Report ECHR z lat 2000-2014, www.echr.coe.int (data dostęu: 23.09.2015 r.).

\section{Wykres 4.}

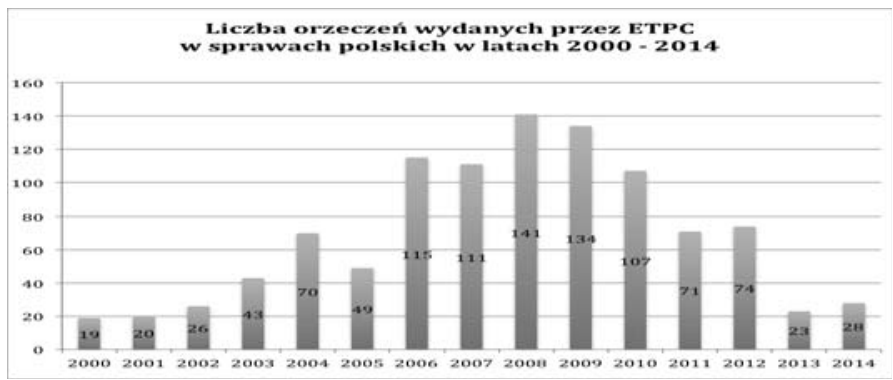

Źródto: opracowanie własne na podstawie European Court of Human Rights Annual Report ECHR z lat 2000-2014, www.echr.coe.int (data dostęu: 23.09.2015 r.). 
Wykres 5.

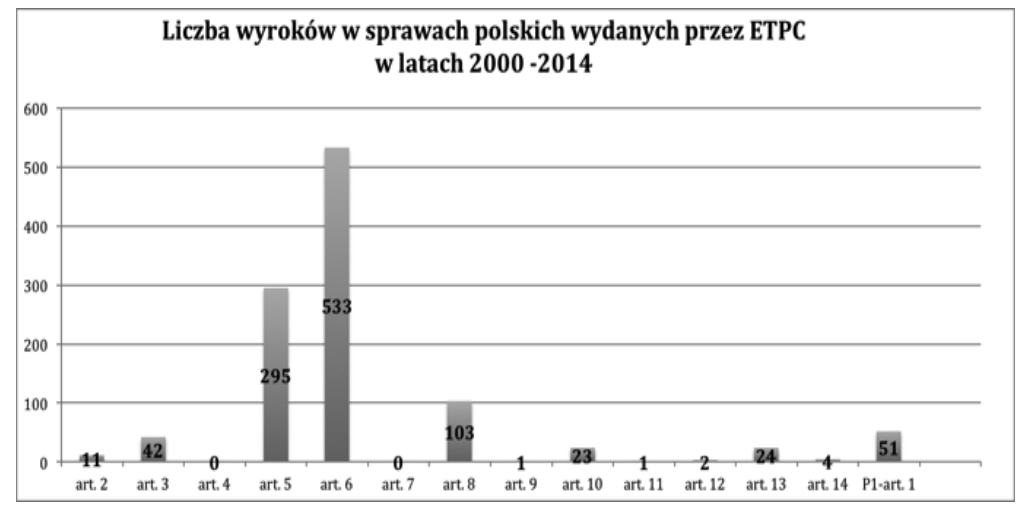

Źródto: opracowanie wtasne na podstawie European Court of Human Rights Annual Report ECHR z lat 2000-2014, www.echr.coe.int (data dostepu: 23.09.2015 r.).

Bardzo ważnym wyznacznikiem przestrzegania standardów EKPC jest liczba wyroków Trybunału uznanych przez KM za wykonane przez państwo. W tym zakresie w przypadku Polski z roku na rok jest to liczba większa, mimo iż liczba wyroków, w których ETPCz stwierdził naruszenie systematycznie maleje (wykonywane są wyroki zaległe z poprzednich lat). Jak wskazuje MSZ w Raporcie z wykonania wyroków Europejskiego Trybunału Praw Człowieka przez Polskę za 2014 r., okres 2014 r. był rekordowy pod względem liczby orzeczeń ETPC wobec Polski uznanych za wykonane przez KM. Zamknięty został nadzór nad wykonaniem aż 357 orzeczeń ws. Polski, w tym aż 117 wyroków merytorycznych ${ }^{27}$. Dla porównania za wykonane uznano w 2013 r. - 278 spraw polskich, w 2012 r. - 164 sprawy polskie, w 2011 r. 58 spraw polskich ${ }^{28}$.

Spadła też liczba wyroków wydawanych przez Trybunał w sprawach polskich. W 2010 r. było ich jeszcze 71, ale w 2014 r. już tylko 28.

Ponadto od kilku lat liczba skarg zawisłych w Trybunale przeciwko Polsce systematycznie spada. Zgodnie z tym trendem, w 2010 r. Polska była na 6. miejscu pod względem liczby skarg w Trybunale, w 2011 r. na 7. miejscu, w 2012 r. już na 10. miejscu, w 2013 r. znalazła się poza pierwszą dziesiątką państw z największą liczbą skarg - na miejscu 12., a w 2014 r. na miejscu $9^{29}$.

27 Raport z wykonania wyroków Europejskiego Trybunału Praw Człowieka przez Polskę za 2014 r., Ministerstwo Spraw Zagranicznych - Pełnomocnik Ministra Spraw Zagranicznych do spraw postępowań przed Europejskim Trybunałem Praw Człowieka, Warszawa 29.5.2015 r., s. 21.

28 Raport z wykonania wyroków Europejskiego Trybunału Praw Człowieka przez Polskę za 2013 r., Ministerstwo Spraw Zagranicznych - Pełnomocnik Ministra Spraw Zagranicznych do spraw postępowań przed Europejskim Trybunałem Praw Człowieka, Warszawa 28.3.2014 r., s. 35.

29 Raport z wykonania wyroków Europejskiego Trybunału Praw Człowieka przez Polskę za 2014 r..., op. cit., s. 21. 


\section{Podsumowanie}

Jak pokazuje praktyka, samodzielność realizacji zobowiązań prawno-międzynarodowych przez Radę Ministrów, wynikających z członkostwa w Radzie Europy, nie byłaby efektywna bez współdziałania z innymi organami państwowymi, w tym sądowymi ${ }^{30}$. Powyższe dane statystyczne wyraźnie wskazują, iż Polska coraz lepiej wywiązuje się z obowiązku wykonywania orzeczeń ETPCz. Z pewnością ważny wpływ na ten proces miało powołanie wyspecjalizowanych struktur, tj. Pełnomocnika Ministra Spraw Zagranicznych do spraw postępowań przed Europejskim Trybunałem Praw Człowieka i Zespołu do spraw Europejskiego Trybunału Praw Człowieka, jak również opracowanie Programu Działań Rządu w sprawie wykonywania wyroków Europejskiego Trybunału Praw Człowieka wobec Rzeczypospolitej. Szeroka współpraca międzyresortowa oraz współpraca z innymi podmiotami ${ }^{31}$ pozwala na efektywną implementację orzeczeń w polskim systemie prawa i praktyce organów krajowych, która od 2007 r. wyraźnie przynosi zdynamizowanie procesu wykonywania wyroków ETPCz.

\section{BIBLIOGRAFIA}

Barkhuysen Tom, Michiel L. Van Emmerik.2005. A comparative view on the execution of the judgments of the European Court of Human Rights. In: European Court of Human Rights, remedies and execution of judgments, 3. British Institute of International and Comparative Law.

Forst Déborah. 2013. „The Execution of Judgments of the European Court of Human Rights - Limits and Ways Ahead". Vienna Journal on International Constitutional Law 3: 1.

Górecki Dariusz. 2012. Polskie prawo konstytucyjne. Warszawa: Wolters Kluwer Polska Sp. z o.o.

Granowska Joanna. 2012. Wykonywanie wyroków Europejskiego Trybunału Praw Człowieka przez Polskę - podstawowe informacje. Materiały na posiedzenie Komisji Praw Człowieka, Praworządności i Petycji w dniu 16 maja 2012 r. Warszawa: Kancelaria Senatu Biuro Prac Senackich.

Grzybowski Marian. 2012. „System rządów w Rzeczypospolitej Polskiej: charakterystyka i diagnoza wątpliwości. Uwagi wprowadzające”. Przegląd Prawa Konstytucyjnego 1: 130-135.

Mażewski Lech. 2009. „Prowadzenie polityki zagranicznej Rzeczypospolitej Polskiej”. Ruch Prawniczy, Ekonomiczny i Socjologiczny LXXI (3): 9-10.

Wydział VII Prawa Europejskiego w Biurze Orzecznictwa NSA. 2014. „Informacje”. Biuletyn Europejski 3 (4): 2.

30 Nie ma wątpliwości, że sądy są jednymi z najistotniejszych instytucji zaangażowanych w wykonywanie wyroków Trybunału. Zwłaszcza że artykuł 6 Konwencji, gwarantujący prawo do rzetelnego procesu sądowego, jest tym postanowieniem Konwencji, którego naruszenie Trybunał stwierdza w swoim orzecznictwie najczęściej.

31 W przedmiocie wzmocnienia skuteczności wykonywania wyroków ETPCz ważny głos zabrała Krajowa Rada Sądownictwa. Ogłosiła to po raz pierwszy w swoim stanowisku w przedmiocie wykonywania orzeczeń Europejskiego Trybunału Praw Człowieka z dnia 16 grudnia 2011 r. Zob. Stanowisko Krajowej Rady Sądownictwa z dnia 16 grudnia 2011 r. w przedmiocie wykonywania orzeczeń Europejskiego Trybunału Praw Człowieka, (w:) Informacja z działalności Krajowej Rady Sądownictwa za 2011 rok, Warszawa maj 2012, s. 29-32, www.krs.pl, (data dostępu: 10.10.2015 r.). 


\section{THE POLITICAL POSITION OF THE EXECUTIVE IN POLAND IN THE ASPECT OF THE EXECUTION OF JUDGMENTS OF THE EUROPEAN COURT OF HUMAN RIGHTS - SELECTED ISSUES}

There are two aspects involved in fulfilling obligations under international law in respect the European Convention for the Protection of Human Rights and Fundamental Freedoms . The first is the introduction of appropriate standards of respect for the rights and freedoms enshrined in the treaty, and the second is the obligation to enforce judgments of the European Court of Human Rights in the case of a stated infringement of the Convention. Both obligations must be carried out simultaneously by the state - which, as a party to the Convention, respects its provisions and fulfills the required international legal obligation. The subject of this paper is to present the powers and legitimacy of the body of the executive in Poland on the execution of judgments of the European Court of Human Rights.

Keywords: European Court of Human Rights, execution of judgments, the executive power, Council of Europe

Słowa kluczowe: Europejski Trybunał Praw Człowieka, wykonywanie orzeczeń, władza wykonawcza, Rada Europy 